\title{
The Development of the Assessment Instrument for Biography Text Learning
}

\author{
Irni Cahyani \\ Department of Indonesian Language and Literature Education \\ STKIP PGRI Banjarmasin \\ Banjarmasin, Indonesia \\ irnicahyani08091987@gmail.com
}

\begin{abstract}
Learning assessment instruments are tools used in the process of collecting, analyzing, and interpreting information regarding students 'ability in learning. Teacher assessment instruments which are used in assessing the ability of students of the biography text in SMAN 6 Banjarmasin include rubric assessment of knowledge and skills, performance, and daily quizzes. However, learning assessment instruments used are still insufficient. The specific objectives of this developmental research were (1) to describe the developed product in the form of assessment instrument for Biography text learning at tenth grade of high school, (2) to describe the trial results, and (3) to describe the revisions of the product. The research method used was research and development proposed by Borg and Gall, with some modification into four steps, namely: (1) analysis of needs, (2) the making of the initial product, (3) expert validation and field testing, and (4) the final product. The data were analyzed by using qualitative and quantitative data analysis techniques. The subjects involved in this research were assessment expert, education practitioners, and students. The results of this development research showed that the assessment instrument already met the aspect of validity, reliability, and practicality that assist teachers.
\end{abstract}

Keywords-Development, The Assessment Instrument, Biography Text, Learning

\section{INTRODUCTION}

Biography text is a text that tells about a person's life written by someone. This text is one of the texts in the 2013 Curriculum being taught at tenth grade of high school. It is important to be taught since via text biography, students can analyze the character or the figure better in the biography text.

Biography text learning, as text-based curriculum in Indonesian context, is implemented in schools based on the 2013 curriculum, a current Indonesian curriculum [1]. Teacher teaches students ranging from the introduction of the structure to the characteristics of the language of the text. The learning objectives of the instruction carried out are based on the competences listed in the curriculum, ranging from Basic Competence 3.14, which is rating thing that can be followed from biography text to Basic Competence 4.15, which is compiling a biography text [1][2]. However, in practice, students do not fully follow the rules in accordance with the structure. When students are asked to learn in accordance with structure, they find it difficult to pour their thoughts. For example, they encounter problems when they are asked to retell the text content that has been read by using their own language and when they are asked to rewrite the text of the biography.

Assessment of learning is the process of collecting, analyzing, and interpreting information regarding students' ability in learning [3]. In a series of the process, a tool to measure the students' ability of so-called assessment instrument is required. Referring to such understanding, it can be concluded that learning assessment instruments are tools or set of tools that are used in the process of collecting, analyzing, and interpreting information regarding students' ability in learning [4][5][6].

The assessment instruments which are used in assessing students' ability of the biography text in SMAN 6 Banjarmasin include rubric assessment of knowledge and skills, performance, and daily quizzes. In practice, first, the teacher always gives an explanation to students before they do exercise and evaluation. On the implementation of performance and daily quizzes, the teacher always gives students a chance to ask if students have not yet understood the meaning of the given problem. However, the assessment instruments used are still insufficient since the assessment instructions are vague, the questions are unclear and the assessment criteria on the rubric assessment of knowledge and skills are not detailed. These weaknesses are found from interviews with teachers of Indonesian language, analysis of teachers' lesson plans, and analysis of student's book of Indonesian language class for tenth grade.

Learning assessment instruments that are used still have weaknesses, so the learning assessment instruments, which meet the requirements of a good learning assessment instruments, are needed in order that teachers are able to measure the ability of the students appropriately. Learning assessment instruments are needed in the form of a test and rubric capable of measuring students' ability appropriately. The learning assessment instruments definitely should be equipped with guidelines/manual of learning assessment instrument, so it is easily implemented by teachers and students [7]. The researchers focused on developing learning assessment 
instruments for biography text with the following Basic Competencies: 3.14 . Rating things that can be followed from the text of the biographies, 3.15 Analyzing aspects of linguistic and semantic in a biography text, and 4.15 Compiling a biography text. This research was aimed at developing the assessment Instrument for biography text learning at tenth grade of high school, particularly at SMAN 6 Banjarmasin and describing the results of the product development.

\section{METHOD}

Due to the limited materials, place, and time to do the research, the researcher has done some modifications on the steps of the research based on the theory of Borg and Gall [8]. These modifications simplify the steps of research into four steps, namely: (1) analysis of needs, (2) the making of the initial product, (3) expert and field testing, and (4) the final product. These steps are described further in the section research and development procedures.

The research development procedures were based on four stages, namely needs analysis stage, the stage of manufacture of the product, the initial stage of experts testing and field trials, and the stage of the final product. The final product stage was the stage of the initial product revision which then produced the finished products [9].

First, the needs analysis phase was the first phase which was conducted by the researcher before making the initial product. Activities at this stage served to find the problems that exist in SMAN 6 Banjarmasin, and to find the solution of the problem. The needs analysis stage included four activities, namely: (1) conducting interviews with Indonesia language teachers; (2) conducting an analysis of the lesson plans used by Indonesian language teachers; (3) conducting an analysis of the textbooks used by the students; and (4) conducting studies of libraries by examining various sources, books on assessment of learning, books about Indonesian language learning for the 2013 curriculum, and books about the text of the biography.

The second stage was the initial stage of product manufacturing. At this stage, the researcher create product specifications which later developed into the early draft product based on a needs analysis. The specifications of this product covered aspects of validity, reliability, and practicality. After the initial product specifications were complete, the researcher developed it into the design of the product, and then the product designs were developed into earlier products. The initial product that has been finished was then validated by expert assessment and education practitioners.

The third stage was the product trial. The trials were divided into two, namely: expert validation and field trials. Expert validation was conducted by assessment test expert. Field trials were conducted by education practitioners and students. From the expert validation and field test, feedback was obtained in the form of numerical data (score) and verbal (suggestions) feedback used to undertake the revision of the product.

The fourth stage was the final product. The last stage was the revision phase which resulted in a finished product of assessment instrument for Biography text learning. At this stage, the researcher did a revision based on assessment and advice obtained from test results of expert validation and education practitioners. The researcher conducted a revision on the product based on the parts of the product which got suggestions of improvement.

The purpose of products trials was to know the validity, reliability, and practicality of the resulting product. The design of the product trials included: trial design, location, time, data types, data collection instruments, and data analysis techniques.

The first one was the design of the trial. The design of this trial was directed at students of class $\mathrm{X}$ from SMAN 6 Banjarmasin as the main target. Trials were carried out to an assessment expert, education practitioners, and students. Assessment from experts and practitioners of education served to assess the tests and assessment rubrics. The students as the main target were requested to do the test. After the students have finished working, they were asked to provide feedback of the test that has been given.

The second one was the location and time of trials. The expert validation was carried out in STKIP PGRI Banjarmasin. Product trials, for education practitioners and students, were conducted in SMAN 6 Banjarmasin. Time trials were adjusted with schedules of the expert, education practitioners, and the students.

The third one was the subjects of the trial. There were three subjects in this development research, namely: lecturer, teacher, and students. The test expert was a lecturer who is competent in the field of competency based assessment. The instruments given to the teacher are in the form of products and product eligibility assessment guidelines. Tenth grade students of SMAN 6 Banjarmasin as the main target in this research were asked to do the test. When they were finished working on the test, the students were given a questionnaire of practicability to assess the test that has been administered.

Fourth is the data type. Data on this developmental research is divided into two, namely: the qualitative data in the form of verbal data and quantitative data in the form of numerical data. The verbal data is a record of the results of the initial needs analysis and advice of expert assessment and education practitioners. Numerical data is obtained from the assessment of expert assessment, education practitioners, and students. This data will be used by researchers in doing the revisions of the product.

The fifth was data collection instrument. This development research used data collection instruments in the form of guidelines, a table of analysis, interviews and questionnaire form. Interview guidelines were addressed to teachers used in the needs analysis stage to obtain information about the 
activities of Basic Competency Assessment 3.14 Rating thing that can be followed from the text of the biographies, 3.15 Analyzing aspects of linguistic and semantic in a biography text, and 4.2 Compiling a biography text. Table analysis was used to analyze students' book and teachers' lesson plans. Questionnaire form was addressed to the expert assessment, education practitioners, and students used at the stage of products trials.

Sixth, the techniques of data analysis in this development research were divided in two, namely: qualitative and quantitative data analysis techniques. Qualitative data analysis techniques were used on the data from interviews with the Indonesian language teacher, analysis of lesson plans, analysis of student's book and suggestions from expert validation and product trials. Quantitative data analysis techniques were performed using the percentage formula of assessment instrument feasibility.

The collected data were subsequently interpreted. The interpretations were based on the following criteria [7].

TABLE I. CRITERIA OF THE DEVELOPED INSTRUMENT

\begin{tabular}{|c|c|c|c|}
\hline \multicolumn{3}{|c|}{ TEST RESULTS } & FOLLOW-UP \\
\hline Categories & Percentage & Qualification & \\
\hline 4 & $85 \%-100 \%$ & Highly feasible & Implementation \\
\hline 3 & $75 \%-84 \%$ & feasible & Implementation \\
\hline 2 & $55 \%-74 \%$ & Pretty Decent & Revision \\
\hline 1 & $<55 \%$ & Unfit & Revision \\
\hline
\end{tabular}

\section{RESULTS AND DISCUSSION}

Development results section contains (1) a description of the product, (2) trial results, and (3) the revision of the product. Further detail is presented as follows

\section{A. Product Description}

Based on a needs analysis through interviews, analysis of teacher's lesson plans, students' book analysis, the researcher made the assessment instrument consisting of three basic competencies that were equipped with the manual use of assessment instruments. These basic competencies include: 3.14 Rating thing that can be followed from the text of the biographies, 3.15 Analizing aspects of linguistic and semantic in a biography text, and 4.15 Compiling a biography text. The developed product included three aspects, namely: validity, reliability, and practicality.

The assessment instruments developed were in the form of test descriptions, practical test, and assessment rubrics. On Basic Competency 3.14, the test description and assessment rubrics were used. In this description, there are two test questions focusing on the understanding of the structure and the content of the biography text (orientation, events and issues, as well as reorientation) and the depiction of superior characters (the way of direct depictions, depictions through the action of the character, and depictions through the description from other characters). The description of rubric assessment test serves to assess the results of the work of the students in doing the test. The description of rubric assessment test included aspects that are assessed, signs of answers, maximum score, details of the score, and the score obtained.

On Basic Competence 3.15, descriptions test, practical test, and assessment rubrics were used. In this description, there were nine test questions focusing on the inferential understanding and evaluation understanding. On this particular test, there was a question focusing on understanding the reorganization (retelling the content of biography text). The description of rubric assessment and practical test serve to assess the results of the work of the students of both tests in analyzing aspects of linguistic and semantic in a biography text. The description of rubric assessment test included assessed aspects, signs of answers, maximum score, details of the score, and the score obtained. Rubric assessment practical tests include assessed aspects, descriptors, the maximum score, details of the score, and the score obtained.

\section{B. The Results of Test Validity, Validity of Assessment Rubric, and Reliability of the Test}

Expert validation was conducted to assess the validity of both description and practical test. The Basic Competence of description tests includes Basic Competences 3.14 and 3.15, while the Basic Competence of practical test included Basic Competences 3.15 and 4.15.

TABLE II. THE RESULTS OF THE VALIDITY OF DESCRIPTION TEST FOR THE BASIC COMPETENCE 3.14 RATE THING THAT CAN BE FOLLOWED FROM THE BIOGRAPHY TEXT

\begin{tabular}{|c|c|c|}
\hline No & Criteria for the Assessment & Percentage (\%) \\
\hline 1 & The validity of the content & 75 \\
\hline 2 & The validity of the contruction & 75 \\
\hline \multicolumn{2}{|c|}{ Average } & 75 \\
\hline
\end{tabular}

TABLE III. THE RESULTS OF THE VALIDITY OF DESCRIPTION TEST FOR THE BASIC COMPETENCE 3.15 ANALYZING ASPECTS OF LINGUISTIC AND SEMANTIC IN A BIOGRAPHY TEXT.

\begin{tabular}{|c|c|c|}
\hline No & Criteria for the Assessment & Percentage (\%) \\
\hline 1 & The validity of the content & 75 \\
\hline 2 & The validity of the contruction & 75 \\
\hline \multicolumn{2}{|c|}{ Average } & 75 \\
\hline
\end{tabular}

The average scores of validity assessment result from the expert on the test description for basic competence 3.14 and 3.15 were both $75 \%$ with the category proper to be implemented. The expert did not give feedback, so no revision was made.

Similarly, the average score of validity assessment result on the practical test for the basic competence 3.15 and 4.15 were also $75 \%$ with the category proper to be implemented.

TABLE IV. THE RESULTS OF THE TEST VALIDITY FOR THE BASIC COMPETENCE 3.15 ANALYZING ASPECTS OF LINGUISTIC AND SEMANTIC IN A BIOGRAPHY TEXT.

\begin{tabular}{|c|c|c|}
\hline No & Criteria for the Assessment & Percentage (\%) \\
\hline 1 & The validity of the content & 75 \\
\hline 2 & The validity of the contruction & 75 \\
\hline \multicolumn{2}{|c|}{ Average } & 75 \\
\hline
\end{tabular}


TABLE V. THE RESULTS OF THE VALIDITY OF THE PRACTICAL TEST FOR THE BASIC COMPETENCE 4.15 COMPOSING A BIOGRAPHY TEXT

\begin{tabular}{|c|c|c|}
\hline No & Criteria for the Assessment & Percentage (\%) \\
\hline 1 & The validity of the content & 75 \\
\hline 2 & The validity of the contruction & 75 \\
\hline \multicolumn{2}{|c|}{ Average } & 75 \\
\hline
\end{tabular}

TABLE VI. THE RESULTS OF ASSESSMENT RUBRIC VALIDITY FOR BASIC COMPETENCY 3.14, 3.15 AND 4.15

\begin{tabular}{|c|c|c|c|c|}
\hline $\begin{array}{l}\text { Compo- } \\
\text { nents }\end{array}$ & $\begin{array}{c}\text { Basic } \\
\text { Competen- } \\
\text { ces } \\
3.14 \\
\text { Description } \\
\text { test }\end{array}$ & $\begin{array}{c}\text { Basic } \\
\text { Competen- } \\
\text { ces } \\
3.15 \\
\text { Description } \\
\text { test }\end{array}$ & $\begin{array}{c}\text { Basic } \\
\text { Competen } \\
\text {-ces } \\
3.15 \\
\text { Practical } \\
\text { test }\end{array}$ & $\begin{array}{c}\text { Basic } \\
\text { Competen- } \\
\text { ces } \\
4.15 \\
\text { Practical } \\
\text { test }\end{array}$ \\
\hline $\begin{array}{l}\text { The } \\
\text { confor- } \\
\text { mance } \\
\text { between } \\
\text { the aspects }\end{array}$ & 75 & 75 & 90 & 75 \\
\hline $\begin{array}{l}\text { The } \\
\text { accuracy of } \\
\text { the answer } \\
\text { keys with } \\
\text { the } \\
\text { question }\end{array}$ & 75 & 75 & 75 & 75 \\
\hline $\begin{array}{l}\text { The } \\
\text { descriptor } \\
\text { with the } \\
\text { task }\end{array}$ & 75 & 75 & 75 & 75 \\
\hline Average & 75 & 75 & 80 & 75 \\
\hline
\end{tabular}

Based on the assessment of the expert, the result of the validity of the assessment rubric for Basic Competences 3.14 and 3.15 showed the average score of $75 \%$, respectively. Furthermore, the average score for the validity of assessment rubric for practical test based on Basic Competence 3.15 was higher, namely $80 \%$. The same average score $(75 \%)$ as the previous competences was also found for the validity of the assessment rubric for Basic Competence 4.15. No further revision was made since the expert did not provide further feedback and all the categories for all average scores showed that the product could be implemented for product trials. In addition to the validity results, the reliability result of the test based on Basic Competence 3.14 was 0.887 , based on Basic Competence 3.15 was 0.859 , and based on Basic Competence 4.15 was 0.805 . These data indicated that the reliability of the test for each basic competence was high.

\section{The Results of the Test Practicality}

For the practicality aspect of description test for Basic Competence 3.14, the assessment expert gave the average score of $75 \%$, while the educational practioner gave the average score of $80 \%$. Similarly, the average score of $75 \%$ was given by the assessment expert to the practicality aspect of description test for Basic Competence 3.15, and the average score of $80 \%$ was given by the practitioner on the same aspect.

TABLE VII. THE PRACTICALITY OF THE TEST

\begin{tabular}{|c|c|c|c|c|}
\hline Validator & $\begin{array}{c}\text { Basic } \\
\text { Competen- } \\
\text { ces } \\
3.14 \\
\text { Descriptio } \\
\text { n test }\end{array}$ & $\begin{array}{c}\text { Basic } \\
\text { Competen- } \\
\text { ces } \\
3.15 \\
\text { Description } \\
\text { test }\end{array}$ & $\begin{array}{c}\text { Basic } \\
\text { Competen } \\
\text {-ces } \\
3.14 \\
\text { Practical } \\
\text { test }\end{array}$ & $\begin{array}{c}\text { Basic } \\
\text { Competen- } \\
\text { ces } \\
3.15 \\
\text { Practical } \\
\text { test }\end{array}$ \\
\hline Expert & $75 \%$ & $75 \%$ & $75 \%$ & $75 \%$ \\
\hline Practioner & $80 \%$ & $80 \%$ & $80 \%$ & $75 \%$ \\
\hline
\end{tabular}

\section{The Results of the Practicality of Assessment Rubric}

TABLE VIII. THE RESULTS OF THE PRACTICALITY OF ASSESSMENT RUBRIC

\begin{tabular}{|c|c|c|c|c|c|}
\hline $\begin{array}{c}\text { Compo - } \\
\text { nents }\end{array}$ & $\begin{array}{c}\text { Valida } \\
\text { tor }\end{array}$ & $\begin{array}{c}\text { Basic } \\
\text { Compet } \\
\text { ces } \\
3.14 \\
\text { Descrif } \\
\text { tion tes }\end{array}$ & $\begin{array}{c}\text { Basic } \\
\text { Compe } \\
\text { tences } \\
3.15 \\
\text { Descri } \\
\text { ption } \\
\text { test }\end{array}$ & $\begin{array}{c}\text { Basic } \\
\text { Compe } \\
\text { tences } \\
3.15 \\
\text { Practi } \\
\text { cal } \\
\text { test }\end{array}$ & \begin{tabular}{|c} 
Basic \\
Competen \\
s \\
4.15 \\
Practi \\
cal \\
test
\end{tabular} \\
\hline \multirow[t]{2}{*}{1} & Expert & 75 & 75 & 75 & 75 \\
\hline & $\begin{array}{c}\text { Practio } \\
\text { ner }\end{array}$ & 90 & 75 & 80 & 75 \\
\hline \multirow[t]{2}{*}{2} & Expert & 75 & 75 & 75 & 75 \\
\hline & $\begin{array}{c}\text { Practio } \\
\text { ner }\end{array}$ & 90 & 75 & 80 & 75 \\
\hline \multirow[t]{2}{*}{3} & Expert & 75 & 75 & 75 & 75 \\
\hline & $\begin{array}{c}\text { Practio } \\
\text { ner }\end{array}$ & 90 & 75 & 80 & 75 \\
\hline
\end{tabular}

Assessment experts and education practitioner also assessed the practicality of the assessment rubric of description test and practical test. Based on the results of expert's assessment, the practicality of the assessment rubric for description test based on Basic Competence 3.14 gained the average score of $75 \%$. The educational practitioner gave higher average score to this aspect, namely 90\%. Moreover, same average scores of $75 \%$ were given by the expert and the practitioner to the practicality of the assessment rubric for description test based on Basic Competence 3.15. The practicality of the assessment rubric for the practical test based on Basic Competence 3.15 gained the average score of $75 \%$ from the expert and $80 \%$ from the practitioner. Same average scores of $75 \%$ were subsequently given by the expert and the practitioner for the practicality of the assessment rubric for the practical test based on Basic Competence 4.15. Thus, with high average scores, the assessment rubric for each basic competence was stated proper to be used.

\section{E. The Results of the Test Practicality from the Students}

The students as the main targets and users in this research gave their feedback of the test which has been administered to them. Based on the assessment of the students on the practicality for description test based on Basic Competence 3.14 , the average score was $80 \%$ and the students stated that 
the text and the test items were easy to understand. Subsequently, the average score of $78 \%$ was given to the practicality for description test based on Basic Competence 3.15. Besides providing assessment, the students also indicated that the test and the test items presented for this basic competence were easy to understand. For the practicality of practical test based on Basic Competence 3.15, the students' responses resulted in the average score of $82 \%$. Similarly, the average score of $82 \%$ was obtained for the the practicality of practical test based on Basic Competence 4.15.

Table IX. THE RESULTS OF THE TEST PRACTICALITY FROM THE STUDENTS

\begin{tabular}{|c|c|c|c|c|}
\hline Aspect & $\begin{array}{c}\text { Basic } \\
\text { Competen- } \\
\text { ces } \\
3.14 \\
\text { Description } \\
\text { test }\end{array}$ & $\begin{array}{c}\text { Basic } \\
\text { Competen- } \\
\text { ces } \\
3.15 \\
\text { Description } \\
\text { test }\end{array}$ & $\begin{array}{c}\text { Basic } \\
\text { Competen } \\
\text {-ces } \\
3.15 \\
\text { Practical } \\
\text { test }\end{array}$ & $\begin{array}{c}\text { Basic } \\
\text { Competen- } \\
\text { ces } \\
4.15 \\
\text { Practical } \\
\text { test }\end{array}$ \\
\hline 1 & 80 & 80 & 80 & 80 \\
\hline 2 & 80 & 75 & 85 & 85 \\
\hline 3 & 80 & 75 & 85 & 80 \\
\hline 4 & 80 & 80 & 80 & 80 \\
\hline Average & 80 & 78 & 82 & 82 \\
\hline
\end{tabular}

\section{F. Product Revision}

Revision of the product was the stage in which the product was revised based on the assessments and feedback from the assessment expert, education practitioners and students. The aspects of the revision included aspects of the validity and practicality, while reliability aspect was not considered for the revision.

Based on the results of development, the instrument developed met the instrument development criteria that is feasible, based on the results of validity, reliability, and practicality of at least 75 . This shows that the instrument can be used in learning. It is in line with the experts' opinion [7] that the instrument of the learning assessment must meet the requirements of a good learning assessment tool so that the teacher can accurately measure the students' ability.

\section{CONCLUSION}

Based on the results of this development research, the assessment instrument already met the aspect of validity, reliability, and practicality. This indicates the instrument is feasible using in assessing students' ability in mastering lesson about biography text, analyzing the aspects of linguistic and semantic in a biography text, and compiling the text of biography.

\section{REFERENCES}

[1] E. T. Priyatni, Desain Pembelajaran Bahasa Indonesia dalam Kurikulum, Jakarta: Bumi Aksara, 2013.

[2] D. Indrawati, Bahasa Indonesia untuk SMA/MA?SMK/MAK Kelas X Semester 2, Jakarta: CV Graha Printama, 2016.

[3] T. Harsiati, Penilaian dalam Pembelajaran, Malang: Um Press, 2011

[4] Kusaeri and Suprananto, Pengukuran dan Penilaian Pendidikan, Yogyakarta: Graha Ilmu, 2012.

[5] Sudaryono, G. Margono and W. Rahayu, Pengembangan Instrumen Penelitian Pendidikan, Yogyakarta: Graha Ilmu, 2013.

[6] N. Sudjana, Penilaian Hasil dan Proses Belajar dan Mengajar, Bandung: Remaja Rosdakarya, 2012.

[7] A. S. Ibrahim and S. Wahyuni, Asesmen Pembelajaran Bahasa, Bandung: Refika Aditama, 2012.

[8] P. Setyosari, Metode Penelitian Pendidikan dan Pengembangan, Jakarta: Kencana Prenadamedia Group, 2013.

[9] N. S. Sukmadinata, Metode Penelitian Pendidikan, Bandung: Remaja Rosdakarya, 2013. 